\title{
COMMUNICATING CULTURE THROUGH LANGUAGE (EXAMPLES OF RUSSIAN ADJECTIVAL PHRASEOLOGY)
}

\author{
COMUNICAÇÃO DA CULTURA ATRAVÉS DA LINGUAGEM (EXEMPLOS DE \\ FRASEOLOGIA ADJETIVA RUSSA)
}

\author{
COMUNICAR LA CULTURA A TRAVÉS DEL LENGUAJE (EJEMPLOS DE \\ FRASEOLOGÍA ADJETIVAL RUSA)
}

\author{
Elmira Ildarovna NAZMIEVA ${ }^{1}$ \\ Elena Anatolyevna ANDREEVA ${ }^{2}$ \\ Kadria Azatovna SAKHIBULLINA ${ }^{3}$
}

\begin{abstract}
In this paper, phraseological units are considered as the most valuable source of information about the culture and mentality of a people of a certain nation; they are often preserved in folklore, customs and traditions, and can be found in literature. In order to recognize a lexical unit as a concept, a keyword of culture is necessary, so it is commonly used, frequently included in phraseological units or proverbs, sayings, and so on. In this study, several phraseological units that reflect traditions and customs of English, Australian and Russian people are discussed. The main focus of the study was on adjectival phraseological units, which are those correlated with adjectives, with the purpose of revealing their meanings, based on various cultural and historical factors. Meanings can be communicated from a variety of positions and even different approaches from which a culture is considered. Phraseological Units enrich each language and are inextricably linked with the culture of the native speakers. More than 900 units of various structures in Russian were found, and then located in sentences from the Russian language corpus. For emphasizing the connection of the units with the culture in which they were formed, examples representing Russian cuisine, stereotypes, climate and others were selected for the article.
\end{abstract}

KEYWORDS: Phraseology. Idioms. Adjectival. Culture. Russian. Communication.

RESUMO: Neste artigo, as unidades fraseológicas são consideradas a fonte mais valiosa de informação sobre a cultura e a mentalidade das pessoas de uma determinada nação; elas são frequentemente preservadas no folclore, costumes e tradições e podem ser encontradas na literatura. Para reconhecer uma unidade lexical como um conceito, uma palavra-chave da cultura que seja comumente usada é necessária, sendo frequentemente incluída em unidades fraseológicas ou provérbios, ditados e assim por diante. Neste estudo, várias unidades fraseológicas que refletem tradições e costumes do povo inglês, australiano e russo são

${ }^{1}$ Kazan Federal University (KPFU), Kazan - Russia. Associate Professor. Candidate of Pedagogical Sciences. ORCID: https://orcid.org/0000-0002-7514-5162.E-mail: nei80@mail.ru

${ }^{2}$ Kazan Federal University (KPFU), Kazan - Russia. Associate Professor of the Department of Philology. Candidate of Philological Sciences. ORCID: https://orcid.org/0000-0002-8418-952X. E-mail: elenaandreeva7788@mail.ru

${ }^{3}$ Kazan Federal University (KPFU), Kazan - Russia. Senior Instructor of the Department of Foreign Languages. Candidate of Philological Sciences. ORCID: https://orcid.org/0000-0003-4604-6058. E-mail: kadriush@yandex.ru 
discutidas. O foco principal do estudo foi sobre as unidades fraseológicas adjetivas, que são aquelas correlacionadas com os adjetivos, com o objetivo de revelar seus significados, com base em vários fatores culturais e históricos. Os significados podem ser comunicados a partir de uma variedade de posições e até mesmo abordagens diferentes das quais uma cultura é considerada. As Unidades Fraseológicas enriquecem cada idioma e estão inextricavelmente ligadas à cultura dos falantes nativos. Mais de 900 unidades de várias estruturas em russo foram encontradas e localizadas em frases do corpo da língua russa. Por enfatizarem a conexão das unidades com a cultura em que foram formadas, foram selecionados para o artigo exemplos representativos da culinária russa, estereótipos, clima e outros.

PALAVRAS-CHAVE: Fraseologia. Expressões idiomáticas. Adjetivos. Cultura. Russo. Comunicação.

RESUMEN: En este artículo, las unidades fraseológicas se consideran la fuente de información más valiosa sobre la cultura y la mentalidad de las personas de una determinada nación; a menudo se conservan en el folclore, las costumbres y las tradiciones, y se pueden encontrar en la literatura. Para reconocer una unidad léxica como concepto, palabra clave de la cultura, es necesario que sea de uso común, frecuente, incluida en unidades fraseológicas o refranes, refranes, etc. En este estudio, se discuten varias unidades fraseológicas que reflejan tradiciones y costumbres de los pueblos ingleses, australianos y rusos. El foco principal del estudio estuvo en las unidades fraseológicas adjetivas, que son aquellas correlacionadas con los adjetivos, con el propósito de revelar sus significados, a partir de diversos factores culturales e históricos. Los significados se pueden comunicar desde una variedad de posiciones e incluso diferentes enfoques desde los que se considera una cultura. Los Phraseological Unit enriquecen cada idioma y están indisolublemente vinculados con la cultura de los hablantes nativos. Se encontraron más de 900 unidades de varias estructuras en ruso, y luego se ubicaron en oraciones de los corpus del idioma ruso. Para enfatizar la conexión de las unidades con la cultura en la que se formaron, se seleccionaron para el artículo ejemplos que representan la cocina rusa, los estereotipos, el clima y otros.

PALABRAS CLAVE: Fraseología. Modismos. Adjetivos. Cultura. Ruso. Comunicación.

\section{Introduction}

Today's language specialists act as linguistic personalities who can efficiently combine general linguistic knowledge with the peculiarities of the associated culture and traditions. Development of human values is reflected in the language, as it is a mirror of culture, showing the reality and creating a worldview specific to every nation or ethnic group who use it as a communication tool. Ethnolinguistics arose between XIX and XX centuries, studying the interaction of linguistic, ethnocultural and ethnopsychological factors in a language. Neither of the components (thinking, culture and language) would exist without one another (TARASOV, 1996). Interethnic communication contexts and socio-cultural behavior of communicants have similarities and differences. 
Language teaching contributes to peace education, which resolves international misunderstandings. Learning a foreign language facilitates multicultural communication, because by means of a foreign language a person can understand foreign perceptual systems, cognitive functions, systems of values, integrating the new information into their own perceptual systems, modifying it accordingly (ROHRBACH; WINIGER, 2001; ECONOMAKIS, 2001; SOBOLEVA, 2017).

It is impossible to separate language from culture (HASELBACH, 2000; MAKSIMOV, 1899). Scholars number from 150 to 250 definitions of culture in the world literature (FROLOV et al., 1989, p. 523).

When experiencing a different civilization, it is essential to master the skills of communicating in their language. When people speak the same language, e.g., English, such as British and Americans, with some differences in their cultures, they also have some variants in the way of communicating information, using various words to denote the same ideas. For example, in the British variant they say "petrol", but not the American "gasoline", or "tram", not a "street car", and et cetera. On the idiomatic level there are many more variant differences and they are harder to understand. The idea of such American phrase as "to put one's foot into it", meaning "to commit public misconduct", in the British variant is delivered by the phrase "to drop a brick", which, in its turn, is unlikely to be understandable for most people in the United States.

Culture includes regular items: ideals, moral norms, traditions, and customs. Together they make up the social rules of conduct, the observance of which makes it indispensable to maintain society as an integrated whole (WHITFORD; DIXON, 1994).

\section{Methods}

The sampling method was used during the work with English and Russian dictionaries. The Russian and English National Language Corpora were used to collect examples for our study.

The identification and classification of Phraseological Units was based on the method of phraseological analysis of A.V. Kunin, which is called the method of phraseological identification and phraseological description. The method of semantic analysis alongside with translation, and the method of comparison for distinguishing linguistic means in different languages were realized. The etymological analysis helped in finding culturally related units. 


\section{Results and discussion}

The scope of this study is adjectival PhUs, i.e., phraseological units correlated with adjectives. The most popular structural type among them is with a comparing component (conjunction as), that is comparative adjectival phraseological units, and the rest are formed with various prepositions (in English), or represented as combinations of notional parts of speech (in Russian) and may all be called adjectival non-comparative PhUs.

In a number of comparative adjectival phraseological units, "a bandicoot" zoomorphism with a negative evaluative seme used to be popular in Australia or is still regionally used there, which is the reason for the presence of a negative evaluative component in the phraseological meaning: "(as) balmy / barmy, mad / as a bandicoot” Australian colloq. - "touched, crazy, out of mind"; "(as) bandy as a bandicoot" austral. colloq. - "bowlegged (about a man)"; "(as) miserable as a bandicoot" Australian. colloq. - "pathetic, unhappy". The negative meanings of these phraseological units are explained by the following factor: "Australians do not like marsupial rats, which cause great harm to their gardens and orchards" (KUNIN, 1984, p. 64). Here is another example of a comparative PhU: "(as) cross (sulky or savage) as a bear" - really angry; "looks like a beast"; "angry as hell". The expression goes back to the time when one of the most popular entertainments was baiting a bear by dogs.

There are adjectival phraseological units that convey the same meaning of "completely bald" in several nations (English, Russian and Australian), but in different lexical ways: Eng. “(as) bald as a billiard ball” Rus. “голый как коленка" (“as naked as a knee”) Austr. “(as) bald as a bandicoot". If in these examples the components-adjectives coincide, then in PhUs "(as) round as a barrel" and "as thick as a barrel", the components-nouns coincide, with which the comparison occurs. Structural and grammatical characteristics of phraseological units may differ: “ободранный как липка" - "as a sheep among the shearers" “fleeced”; or "(as) blind as a bat (more rarely "as a beetle, as mole)" translated into Russian as "a blind hen" - "слепая курица".

Differences in the ways of expressing the same thought describe a picture of a nation's life, its habits and ideals; show a negative or positive attitude to things. We can assume that daisy flowers may be loved by most British people, unlike most Russians who prefer roses. We can guess that among many British people it was popular to paint walls (or they value painting more) and less than Russians they could be engaged in gardening: "(as) fresh as a daisy (as a rose or as paint)" Rus. “свежа как роза" - "fresh as a rose”, “свежий как огурчик” "fresh as a cucumber". 
Thus, we have to take into account the peculiarities inherent in each ethnic group, in order to avoid misunderstandings. The language of a nation and its culture are inextricably linked and should be studied in conjunction with each other. PhUs are the national wealth of each language, and, therefore, are also inextricably linked with the culture of the people who speak the language.

\section{Adjectival phraseological units in the Russian language}

All comparative phraseology of the Russian language (as well as of other Slavic languages) may be considered to be of two main types: comparative stable phrases ( $\mathrm{CSPh})-$ idioms, and CSPh - phraseological units (ROIZENZON, 1971). Phraseologisms can act as a form that is not filled with any content from the point of view of modern Russian ("гол как сокол” - “dog poor”, “глупый как пробка” - “dumb as a bag of hammers”, and etc.), or reflect the real situation of comparison (“черный как уголь” - "black as coal”, “трусливый как заяц” - "as timid as a hare", and etc.). The reason for the loss of the comparison situation is the disappearance of the object from the everyday use, whose name is stored as one of the components. For example, those people who call soft blond hair "white as flax" are hardly familiar with the technology of making linen yarn. The lack of direct comparison may not be due to the loss of reality, but to a lack of awareness in various areas of life, or lack of knowledge of the sources of expression (“богат как Крез” - "as rich as Croesus”). The expression can be shortened with time, when the usual is understood from a half-word, for example: “свеж как огурчик” (fresh as a freshly picked cucumber) or “красный как рак” (red as a boiled crayfish) (IONOVA, 1975).

Working with dictionaries, more than 900 units of various structures in Russian were found, and afterwards located in sentences from the online Russian language corpora. Several examples of such phraseology with some commentary on their origin are given below:

- «Гол как сокол» - means "someone absolutely poor, who has nothing" or "dogpoor". It comes from a comparison with the old batterer "sokol", which was a completely smooth cast-iron disk, attached to chains (MAKSIMOV, 1899).

Examples from literature: a) Dog-poor, he came into the house which had all been prepared before and now even threatens (Vasily Shukshin, "Wolves”, 1967). 
b) After searching them and collecting the trophies - nothing will hinder me, I am penniless and dog-poor, - rushed on, hiding in the tangles of the metropolis sewers (V.G. Poselyagin, "Fugitive", 2015).

- «Губа не дура» - colloquial, but still used expression. It means that someone has a good taste, knows what to choose, to prefer. It comes from the proverb: "Губа не дура, язык не лопата; знают, где кисло, где сладко" meaning "One knows on which side bread is buttered; they know where it is sour, where it is sweet."

Examples: a) He knows on which side bread is buttered - huh? (I.S. Turgenev "Nakhlebnik", 1848).

b) And you, Misha, know on which side bread is buttered. (A. P. Chehov, "Leshiy", 1888).

- «Косая сажень в плечах» - a person of powerful build, very broad in the shoulders, or "a great hulk of a man". In the old days in Russia, before the introduction of the metric system of measures, in addition to the ordinary fathoms equal to three arshins, there was also a small fathom in everyday life, equal to two and a half arshins, and an oblique fathom, equal to the distance from the end of the big toe of the right foot to the end of the middle finger of the raised-up left hand (DAL, 1914).

Ex.: a) But she was rather tired of this loving spouse - a strong guy, a great hulk of a man, and who does not want to find a job in order to at least put food on the table (Victor Seleznev, "To be married is good, but to be at home is better", 2001).

b) Well, when they talk about extraordinary physical strength, they say, for example: a hefty, a great hulk of a man, like a cupboard, Athanasius eight by seven, a big fellow, a towser (Vladimir Cherkasov, "Black Box”, 2000).

c) And he, a great hulk of a man, but not good - therefore, they are afraid to accept someone like him, he will tell others that the soldiers are against the law of God (L.N. Tolstoy, "Full collection of works", 1909).

In order to better emphasize the linkage between the units and the culture in which they were formed, examples representing Russian cuisine have been selected. By their structure, some of the units could also be referred to substantive and verbal types. Stewed turnip and porridge used to be very popular types of food in Russia. Nowadays these words are used to express various characteristics of things or people: 
- “каши просят" - about worn out shoes or boots, in holes, requiring repair; "каши не сваришь" - it is impossible to negotiate or do anything with someone; “мало каши ел” - уоung and still not experienced to take on any serious business, "wet behind the ears"; “каша в голове” - somebody can't think clearly; “каша во рту” - someone speaks in a wrong way, says the words incorrectly;

• “дешевле пареной репы” - “as cheap as dirt”; “проще пареной репы” - “as easy as falling off the log".

So sometimes it is possible to convey the meaning of the phrases using idiomatic equivalents in Enlgish. As we can see, the phraseological units may describe a condition, tastes, looks, character features, and so on. They all can be categorized according to their semantics. Those multiple elements of life comprise the Russian culture and reflect it. We can find equivalent phrases in English, as well, for such units as:

- «как шёлковый» - meaning “timid, obedient”, it is “(as) good as gold”, “(as) meek as a lamb”; «как щепка» - meaning "very thin, skinny” or “(as) thin as a rail (a rake, a reed)", “(as) skinny as a tooth pick”; «чёрный как смоль» - jet black, pitch-black; coal-black; «как спичка» - "(thin (spindly, etc.) as a matchstick (a rail)".

Often a language reflects the cultural phenomena based on the historically-developed context, climate and geographic position, or socio-economic conditions of its country. It may often be impossible to use direct translation if dealing with set-phrases. It can be challenging to demonstrate such aspects in translation without knowing about the common cultural features in the target country.

Phraseological Units based on stereotypes about Russia have been picked, as well as on what could be considered ordinary for the Russian area. When browsing the phraseological list, many phrases on alcohol-intoxication were spotted:

- «под градусом», «под мухой», «под хмельком (хмелем)», «под шефе» - in condition of light intoxication, tipsy;

- «как зюзя (в зюзю)», «в стельку», «мертвецки пьян», «в доску пьян(ый)», «под балдой», «на бровях», «едва на ногах стоит», «на ногах не стоит» - about a very drunk person (the latter two also describing a weak person because of sickness or exhaustion);

- «как стёклышко» - either meaning something clean and sparkling, or an absolutely sober person, a morally pure person.

Another repeated example is about snow in Russia: 
- «зимой снега (снегу) не выпросишь» - about a cheap, greedy person; «как прошлогодний снег нужен» - not needed at all.

- An example from Russian folklore, fairy tales: «на курьих ножках» - about a small, shabby, not attractive building.

- Critical attitude towards Russian roads has been reflected in the phrase «ни проехать ни пройти (ни пройти ни проехать) » - about a very bad, dirty, broken road, or about a crowd.

- Russian houses have always been surrounded by high fences and gates, so the phrase «ни в какие ворота не лезет» - means it won’t do, or “doesn't hold water”, or literally meaning "it won't fit in the space between any open gates".

- There used to be tsars in Russia, so the expression «без царя в голове» - "without a tsar in his head" means someone very stupid, obtuse.

- The etymology of the phraseological unit «всегда готов» (“always prepared”, which may also be translated as "always ready to do something") comes from the Soviet Russian period, when the Pioneers used this phrase as a motto.

Language plays a special role, being a means of conveying social experience of an individual. The idea of the sociality of language should be understood as a unity of language and culture, language and society. At any point in the development of a culture its language reflects it fully and adequately. The society, members of the national cultural and linguistic community, is the driving force of the progress and of any changes in a language.

\section{Summary}

Phraseological units deserve special attention when learning a foreign language and understanding the culture of a nation of the target language. According to definition of Pimenova (2002, p. 6), we call a phraseological unit: a) stable combinations of words with complicated semantics that are not formed by generating structural-semantic models of variable values, b) separate words with a reinterpreted meaning, called single-word idioms, c) sentences of proverbial type. A proverb or a saying, an idiom or a stable combination of words with complicated semantics, are created by people within their cultural environment. The way the meaning is conveyed depends on cultural peculiarities. Maslova (2001, p. 82), in her study guide "Linguoculturology", writes that phraseological units are always addressed to the subject, i.e., they arise in order to interpret the world, evaluate and express a subjective attitude towards it. Arsentieva (2006, p. 22) and Abdullina, Ageeva and Artamonova (2019), notes that positive, 
negative or neutral evaluative components owe their appearance to the content of any extralinguistic phenomenon: custom, tradition, beliefs, superstitions, legends, myths, fairy tales, and etc. Thus, the study of PhUs contributes to a deeper understanding of a nation's culture and language.

Phraseological units that reflect traditions and customs of English people, for example, are: "good wine needs no bush" - meaning "good wine does not need a label"; "A good product praises itself" (according to the old custom, innkeepers hung out ivy branches as a sign that there was wine for sale); "beat the air (or the wind)" - "to try in vain, wasting energy"; "mill the wind", "crush water in a mortar" (the expression comes from the medieval custom of waving arms as a sign of victory, when the enemy did not come to court for the honor to resolve a dispute with a weapon) (KUNIN, 1972, p. 25-26).

"One of the fundamental functions of a language is to be an instrument of creation, development, storage and transmission of culture" (ANDREYEVA; KORNEVA; SAKHIBULLINA, 2019; MASLOVA, 2001, p. 2). A huge amount of information comes through a word, and the success of a person in society depends on how well s/he knows the word, being capable of perceiving the secrets of the language. Phraseological units are the most valuable source of information about the culture and mentality of people; they are often preserved in folklore and traditions. In order to recognize a lexical unit as a concept, a key word of culture, it should be commonly used, frequent, included in phraseological units or proverbs, sayings, and the like. Phraseology is different in every language. Phraseological units are the "mirror of the nation's life".

According to Kunin's (1972, p. 8) definition, a phraseological unit is a stable combination of lexemes with a fully or partially reinterpreted meaning.

Vast spaces, labor and intellectual activity, the storm of their feelings people measure through themselves (Rus. “каша в голове” (meaning: "head in a muddle”), “насколько хватает глаз" (as far as the eye can see); “голова на месте” (about someone "smart and clever"); "on cloud seven (or nine)"; "green with envy"; "out of the way”; etc.).

In the inner form of most phraseological units there are such meanings that give them a cultural ethnic flair. For example, the phraseologism “сбоку припёку” - literally translated as "on the side of the bread" (about something unnecessary, not significant, "fifth wheel") arose from the real situation of baking bread, when there are surges of dough on the side of the loaf base that are not eaten (MASLOVA, 2001, p. 83). The semantics of such phraseological units can be interpreted from the standpoint of value attitudes and stereotypes inherent in the mentality of a nation, i.e., in terms of national culture: the fact that the dough is separated from 
the base of the loaf is not good; besides, it cannot be used for food, because it burns; it is covered with a crust, therefore, the growths on the side of the loaf are not needed.

\section{Understanding nation/personality}

"The concept of personality makes sense only in the system of social relations, only where it is possible to speak of a social role and a set of roles" (FROLOV, 1989). Where there are people, their activities, and relations, there is also culture. Creating the objective world of culture, people at the same time develop themselves as personalities, as social beings, form their creative abilities. All these processes would have been impossible without the parallel development of human speech activity, causing the interaction of individuals both within a single culture and among other cultures.

The linguistic personality exists, manifests itself and is formed in the activities and communication of the cultural environment in which it is located. Or, on the contrary, proceeding from the language, one can understand a lot about the culture of another nation. Language is the first difficulty that stands in our way of understanding another nation.

English has become an international language due to its relative grammatical simplicity and flexibility (ECONOMAKIS, 2001, p. 4). For example, part of the speech of many English words is determined by their place in the sentence. At first glance, it is unusual and incomprehensible for a Russian person, since one word in English can be either an adjective, or a noun, or a verb. Many words, such as "drink," "kiss," "look," etc., can be used as nouns, verbs, and adjectives: we "chill" champagne in ice, and we feel a "chill" in the morning. The advantages of the English language are felt in business, where its compactness, clarity and consistency are indispensable. For example, in English there is no equivalent for the Russian expression "in two words": they say "in a word" (in one word). We have to take into account the linguistic peculiarities within each nation, in order to avoid misunderstandings.

\section{Conclusions}

The meaning can be conveyed in different lexical ways, the culturally related meaning is better communicated through such lexical expressions as phraseological. Structural and grammatical characteristics of phraseological units may differ. Differences in the ways of expressing the same thought describe a picture of a nation's life, its habits and ideals; show an attitude to things. We have to take into account the peculiarities inherent in each ethnic group, 
in order to avoid misunderstandings. The language of a nation and its culture are linked and should be studied in unity. Phraseological units may describe a condition, tastes, looks, character features, and so on. They all can be categorized according to their semantics. It can be challenging to demonstrate such aspects in translation without knowing about the common cultural features in the target country.

As seen from the examples, the language verbalizes the national cultural picture of the world, as well as stores and passes it from generation to generation. While culture communication can be realized through conveying the meaning of such lexical items as phraseological units, the latter act as information pieces out of another cultural worldview, and the language learners try to combine them with the existing cultural view in their minds, given by their native language, so interaction of worldviews happens.

ACKNOWLEDGEMENTS: The work is performed according to the Russian Government Program of Competitive Growth of Kazan Federal University.

\section{REFERENCES}

ABDULLINA, L. R.; AGEEVA, A. V.; ARTAMONOVA, E. V. Corpus linguistics tools for loanwords and borrowings studies. Journal of Research in Applied Linguistics, v. 10, p. 3341, 2019.

ANDREYEVA, Y. A.; KORNEVA, I. G.; SAKHIBULLINA, K. A. Values and anti-values in figurative phraseological units in the russian and german languages. Humanities \& Social Sciences Reviews, v. 7, n.4, p. 427-432, 2019.

ARSENTIEVA, E. F. Phraseology and phraseography in a comparative aspect: (on the material of Russian and English languages). Kazan State University, 2006. 172 p.

DAL, V. I. The explanatory dictionary of the living great russian language. 4. ed. Saint Petersburg, 1914. v. 4, p. 9.

ECONOMAKIS, E. How different we are! Saint Petersburg: KARO, 2001. 224 p.

FEDOROV, A. I. Phraseological dictionary of the russian literary language. Moscow: AST, 2008. 828 p.

FROLOV, I. T. et al. Introduction to philosophy. Textbook for universities: in 2 parts. Moscow: Politizdat, 1989. 639 p.

HASELBACH, A. Learning in polylogues. Processes of social insertion into overlapping culture. Lifelong Learning in Europe, v. 5, n. 4, p. 196-200, 2000. 
IONOVA, I. A. Adjectival phraseological units with a comparison structure in modern russian. Russian language at school. Prosvesheniye, 1975. n. 4, p. 96-101.

KUNIN, A. V. English-Russian phraseological dictionary, about 20,000 phraseol. 4. ed. Moscow: Rus. lang., 1984. 942 p.

KUNIN, A. V. Phraseology of modern English. The experience of a systematic description. Moscow: Intern. Relations, 1972. 288 p.

LUBENSKAYA, S. I. Russian-english phraseological dictionary. Moscow: Languages of Russian culture, 1997. 1056 p.

MAKSIMOV, S. V. Krylatye slova. Saint Petersburg, 1899. 261 p.

MASLOVA, V. A. Linguoculturology: a textbook for university students. Moscow:

Publishing Center “Academy", 2001. 208 p.

PIMENOVA, N. D. Comparative analysis of phraseological units with componentornithorous in the english and turkish languages. Kazan, 2002. 22 p.

ROHRBACH, R.; WINIGER, E. Tandem statt unterricht [Tandem instead of teaching]. Comano, Switzerland: Universitat Bern, 2001. p. 64-68.

ROIZENZON, L. I. Notes on Russian comparative phraseology. Questions of phraseology, Samarkand, p. 12-21, 1971.

SOBOLEVA, N. P. Linguoculturological aspects of the contextual use of phraseological units in advertising slogans. Vestnik Tomskogo Gosudarstvennogo Universiteta, Filologiya, v. 45, p. 139-149, 2017.

TARASOV, E. F. Intercultural communication: a new ethnology of the analysis of language consciousness. Ethnocultural specificity of language consciousness. Moscow, 1996. $227 \mathrm{p}$.

TIKHONOV, A. N. Phraseological dictionary of the russian language. Moscow: Russian language-Media, 2007. $338 \mathrm{p}$.

WHITFORD, G. K.; DIXON, R. J. English-Russian vocabulary and phraseological dictionary. American idioms: 4500 units. Moscow: Zest, 1994. 190 p. 


\section{How to reference this article}

NAZMIEVA, E. I.; ANDREEVA, E. A.; SAKHIBULLINA, K. A. Communicating culture through language (examples of russian adjectival phraseology). Rev. EntreLínguas, Araraquara, v. 7, n. esp. 3, e021041, Sep. 2021. e-ISSN: 2447-3529. DOI: https://doi.org/10.29051/el.v7iesp.3.15698

Submitted: $10 / 01 / 2021$

Required revisions: 20/03/2021

Approved: $23 / 06 / 2021$

Published: 01/08/2021 